\title{
Expression of Phytase gene in transgenic maize with seed-specific promoter 27-kDa y Zein and constitutive promoter CaMV $35 \mathrm{~S}$
}

\author{
Ririn Septina Arthasari*, Rani Agustina Wulandari, and Panjisakti Basunanda \\ Department of Agronomy, Faculty of Agriculture, Universitas Gadjah Mada \\ Jln. Flora no. 1, Bulaksumur, Sleman, Yogyakarta 55281, Indonesia \\ *Corresponding author: rani@ugm.ac.id
}

\section{Article Info}

Received : 04 ${ }^{\text {th }}$ February 2021

Revised : $12^{\text {th }}$ April 2021

Accepted: $27^{\text {th }}$ May 2021

Keywords:

Animal feed, enzyme, gene

expression

\begin{abstract}
Phytase enzymes are applied to animal feed to help animals absorb more nutrients. The use of feed raw materials containing phytase enzymes is expected to reduce the cost of animal feed production. Efforts to increase the phytase content in maize were carried out by improving genetics, in the way of assembling transgenic plants containing high phytase content. The 27-kDa $y$ Zein promoter is a specific promoter that expresses genes in caryopsis, and promoter CaMV $35 \mathrm{~S}$ is a constitutive promoter that controls gene expression in all tissues and generally does not depend on the growth phase. Transgenic maize was transformed using Agrobacterium tumefacien infection method on maize B104. The reverse transcriptase polymerase chain reaction (RT-PCR) approach was used to examine the expression of phytase genes in leaves, roots, and caryopsis was done 10, 20, and 30 days after pollination (DAP). The phytase enzyme activity test was also carried out by using the colorimetric phosphomolybdate analysis method to see the phytase enzyme activity in unit. $\mathrm{gg}^{-1}$. The results showed that the phytase gene in transgenic plants with the 27-kDa $\gamma$ Zein promoter was highly expressed in maize caryopsis, but in line Z6.10 was also expressed in leaves, while in the CaMV 35 s promoter the phytase gene was only expressed on the leaves. Phytase enzyme activity showed that transgenic maize was higher than non-transgenic maize.
\end{abstract}

\section{INTRODUCTION}

Plants such as cereals, nuts, and seeds store phosphorus ( $\mathrm{P})$ in the form of phytic acid $\left(\mathrm{C}_{6} \mathrm{H}_{18} \mathrm{O}_{24} \mathrm{P}_{6}\right.$ or Ip6) (Belgaroui et al., 2014, Singh et al., 2018). Phytic acid retains $60 \%$ to $90 \%$ of inorganic phosphorus in legumes, oil seeds, and cereals, rendering it is unavailable for metabolic reactions in living systems (Corrêa dan Arajo, 2020). Phytic acid is a chelate for magnesium ( $\mathrm{Mg})$, calcium ( $\mathrm{Ca})$, sodium $(\mathrm{Na})$, iron (Fe), zinc ( $\mathrm{Zn}$ ) and potassium (K), as well as in some cases of protein and carbohydrates (Coulibaly, 2011). Grains are the main ingredient in animal feed manufacturing. In maize kernels, phytic acid is an insoluble phosphate derivative (Borlini et al., 2019). Structurally phytic acid has a limited ability to be digested, so phytase is indispensable for livestock (Lei et al., 2013). Phytic acid in livestock feed reduces nutrient uptake by reducing the activity of digestive enzymes in the small intestine, forming protein bonds and digestive enzymes in the stomach, reducing pepsin activity, and forming bonds with endogenous nutrients, which result in lower in nutrient absorption rate (Woyengo and Nyachoti, 2013).

Phytase enzymes break down phytic acid (Myoinositol 1,2,3,4,5,6-hexakisphosphate) into myoinositol and inorganic phosphate, and myo-inositol phosphate into monophosphates (Selle and Ravindran, 2007). The majority of phytases belongs to the histidine acid phosphatases family. Via the formation of myo-inositol phosphate intermediates, the enzymes hydrolyze phytic acid are turned into

How to cite: Arthasari, R.S., Wulandari, R.A., and Basunanda, P. (2021). Expression of Phytase gene in transgenic maize with seed-specific promoter 27-kDa $\gamma$ Zein and constitutive promoter CaMV 35S . Ilmu Pertanian (Agricultural Science), 6(3), pp. 148-155. 
phosphoric acid and myoinositol in a staircase fashion (Yu et al., 2012; Dersjant et al., 2015). Based on the position of phosphate groups in phytate molecules that are hydrolyzed first, the Enzyme Nomenclature Committee of the International Union of Biochemistry identifies four phytases: 3-phytases (EC 3.1.3.8), 4-phytases or 6-phytases (EC 3.1.3.26), 5-phytases (EC 3.1.3.72) (Reddy et al., 2013). In maize seeds, phytase can boost cellular iron uptake, and the rate of iron uptake has been linked to phytase expression (Singh and Satyanarayana, 2011)

The addition of phytase enzymes to animal feed production causes the price of animal feed production to be high (Gontia et al., 2012). The use of feed raw materials containing phytase enzymes is expected to reduce the production costs of animal feed. Efforts that can be made are to improve the quality of feed raw materials by increasing the phytase enzyme content in it. Transgenic maize expressing phytase can replace phytase enzyme addition. Phytase enzymes have been expressed in transgenic plants in a variety of plant species. To improve the nutrition of plants and animal phytase, it has been produced in rice (Joshi et al., 2015) and maize (Geetha et al., 2019). Plants produce phytase as a substitute for commercial phytase in Chlamydomonas (Erpel et al., 2016) and Brassica napus (Wang et al., 2013). The development of nutritionally enhanced cereals to combat iron and zinc deficiency in malnourished people, especially women and children, in wheat (Abid et al., 2017). Overexpression of phytase improves plant growth in Arabidopsis under osmotic stress and when combined with phosphate deficiency (Belgaroui et al., 2018).

The aim of this study was to create maize with a high phytase enzyme activity expressed in maize seeds, which can be used as a fodder feed content. The transgenic maize expresses phytase genes. Promoters play a significant role in controlling the expression of inserted genes in transgenic plants. The production of new maize cultivars with high phytase was based on the analysis of phytase gene expression in plant organs and seed development, as well as the analysis of phytase enzyme activity. To assess differences in phytase gene expression in transgenic maize, the researchers used the $27-\mathrm{kDa}$ $\gamma$-Zein promoter, which expressed genes in caryopsis, and the CaMV 35S promoter, which is a constitutive promoter that regulates gene expression in all selected tissues. In order to grow new cultivars of maize with high phytase content, this study was conducted to determine how the expression of the inserted gene in transgenic maize carried the phytase gene on the 27-kDa $\gamma$-Zein promoter and the CaMV 35 s promoter.

\section{MATERIALS AND METHODS}

The research was conducted from December 2018 to January 2020 at the Genetic Engineering Laboratory PT. BISI International, Tbk., Pare, Kediri, East Java. Transgenic maize of phytase was obtained from the transformation of immature embryos from B104 maize which was followed by the method of Frame et al. (2011) by modifying selection using hygromycin antibiotics. Immature embryos from B104 Maize were infected with $A$. tumefaciens EHA105 to produce transgenic maize. To obtain T1 seeds, the transgenic maize was created and advanced in the greenhouse. T1 seeds were planted and plant tissue samples (leaves and roots) were taken for gene expression analysis. T1 plants produced T2 seeds for analysis of gene expression and phytase enzyme activity.

DNA isolation was carried out by the $2 \%$ CTAB method to select plants that were positive for phytase genes having been inserted in transgenic plants via PCR using specific primers for phytase. Leaf samples were taken when the plant was 14 days old. The results of positive phytase plant DNA were used for the analysis of phytase gene expression. DNA isolation was carried out on leaves, roots, and seeds which would be analyzed for enzyme activity. The seeds used in the phytase gene expression analysis were taken at the age of 10, 20 and 30 days after pollination (DAP).

Total RNA was extracted using Trizol (GENEzol тм Reagent GZR050) as directed by the manufacturer. The consistency of total RNA used as a template for synthesizing complementary DNA (cDNA) by RivertAid reverse transcriptase (Thermo Scientific ${ }^{\mathrm{TM}}$ ) was determined using electrophoresis in a total reaction volume of $20 \mu \mathrm{L}$. The reverse transcriptase PCR (RT-PCR) approach was used to examine phytase gene expression in leaves, roots, and, seeds. cDNA amplification was carried out using phytase primers as target genes and actin primers as an internal control. Phytase forward (5'GAATTCCAGTCTGAACCAGAATTGAAGTTG'3) and reverse (5'CCCGGGCAAGGAACAGGCTGGGATTCT- 
GGC'3) were used to amplify phytase gene. Actin primer forward (5'CAGGTGATGGTGTGAGCCACACGGTTCC' 3 ) and reverse (5'GGCGATTCCATGCCAACAAGGGATGG'3) were used to amplify actin as internal control of housekeeping gene. Phytase primers would produce amplicon at $1200 \mathrm{bp}$ and actin gene at 352 bp. cDNA samples were amplified using PCR reagents from Bioline DNA Polymerase and dNTP Mix (Bioline ${ }^{\mathrm{TM}}$ ), and using the GeneAmp ${ }^{\circledR}$ PCR system 9700 (Applied Biosystems). PCR applied $2 \mu \mathrm{L}$ cDNA, $0.5 \mu \mathrm{L}$ forward and reverse primer $2.5 \mu \mathrm{L}$ $10 \times \mathrm{NH} 4$ Reaction Buffer, $3 \mu \mathrm{L} 50 \mathrm{mM} \mathrm{MgCl}, 0.5 \mu \mathrm{L}$ dNTP mix, $0.25 \mu \mathrm{L}$ Biotaq polymerase, and Nuclease free water up to $25 \mu \mathrm{L}$. Each well was filled with equal amount of PCR product, and the transcription level was calculated semi-quantitatively. In $1 \%$ agarose gel stained with Ethidium Bromide, PCR products were visualized. The Alpha Imager MINI (Alpha Innotech) was used to visualize electrophoresis materials.

The single kernel of maize was grounded into powder using mortar and liquid nitrogen. Moeller et al. (2009) identified maize powder $50 \mathrm{mg}$ resuspended in $500 \mu \mathrm{L}$ sodium phosphate buffer $\mathrm{pH} 6.6$ plus $\mathrm{NaCl}$, EDTA (pH 8), TritonX-100, and protease inhibitor cocktail per mg of maize powder. Samples were incubated with a shaker at $37^{\circ} \mathrm{C}$ for $2 \mathrm{~h}$ and then centrifuged at 13,000 rpm for $20 \mathrm{~min}$. The Bradford method was used to determine total dissolved protein (TSP) using BSA (Bovine serum albumin) as a standard (Bradford, 1976). Total dissolved protein of $20 \mu \mathrm{L}$ Bradford was added with a concentration of $1 \times$ as much as $1 \mathrm{~mL}$. The absorbance value at $595 \mathrm{~nm}$ was measured after 5 minutes of incubation at room temperature. Protein extract was used for the analysis of the activity of the phytase enzyme.

Phytase enzyme activity was measured by the phosphomolybdate colorimetric analysis method (Bae et al., 1999). Total dissolved protein as much as $75 \mu \mathrm{L}$ from transgenic maize and non-transgenic maize and the standard were reacted with phytic acid substrate as much as $300 \mu \mathrm{L}$ at $37^{\circ} \mathrm{C}$ for 20 minutes. The enzyme reaction was stopped by adding trichloroacetic acid and providing dye solution containing ammonium molybdate dissolved in sulfuric acid $5.5 \%$ and added with $2.7 \%$ ferrous sulfate. It was incubated for 5 minutes with a visible absorbance values at a wavelength of $700 \mathrm{~nm}$. An enzyme unit is defined as $1 \mu \mathrm{mol}$ phytase released per minute under test conditions. The activity of enzymes was measured using $\mathrm{KH}_{2} \mathrm{PO}_{4}$ as a norm which reacted similarly to total dissolved protein. Under test conditions, an enzyme unit is described as $1 \mathrm{~mol}$ phytase released per minute.

\section{RESULTS AND DISCUSSION}

\section{Phytase expression in transgenic maize}

Endosperm specific promoters applied 27-kDa $\checkmark$ Zein and constitutive promoters CaMV 35 S were used in this study to express phytase genes. In this gene expression experiment three lines of transgenic plants were used both in transgenic maize plants with 27-kDa $\gamma$ Zein promoters and CaMV 355 promoters, for phytase of 27-kDa $\gamma$ Zein promoters gene expression analysis, which was carried out at number Z6.10, Z5.10, and Z5.8. The CaMV 35 S phytase, was also tested for gene expression on three numbers, namely C7, C17, and C16. RNA samples for phytase gene expression were taken from the leaves, roots, and seed at the development stage of maize fruit when the fruits were aged 10,20 , and 30 days after pollination. The samples taken came from the same plant.

The expression of phytase genes in transgenic plants with the 27-kDa $\gamma$ Zein promoter was measured in three numbers, and the results revealed that the expression of phytase genes in leaves for number Z6.10 suggested phytase transcription. It was an amplification that produced a band at $1200 \mathrm{pb}$ in accordance with $1200 \mathrm{pb}$ positive plasmid control used. In number Z5.10 and Z5.8 there was no amplification that produced a band at $1200 \mathrm{bp}$ in leaf samples. This indicates that at number $\mathrm{Z} 5.10$ and $Z 5.8$ there was no phytase gene expression. At the root of the transgenic phytase plant with 27-kDa $y$ Zein promoter, the results that the phytase gene was not expressed at the root of the transgenic plant can be seen from the absence of the band produced in Figure 1a.

Phytase gene expression in transgenic maize kernel with 27-kDa y Zein promoter was observed at three different numbers and the results showed that at number Z6.10, Z5.10 and Z5.8, there was phytase expression that could be observed only in immature seeds aged 10 and 20 DAP, whereas in mature seeds (30 DAP) phytase gene expression can no longer be observed. This can be seen from the amplification of the ribbon at $1200 \mathrm{bp}$ in seed at the age of 10 and 20 DAP, whereas for old seed 


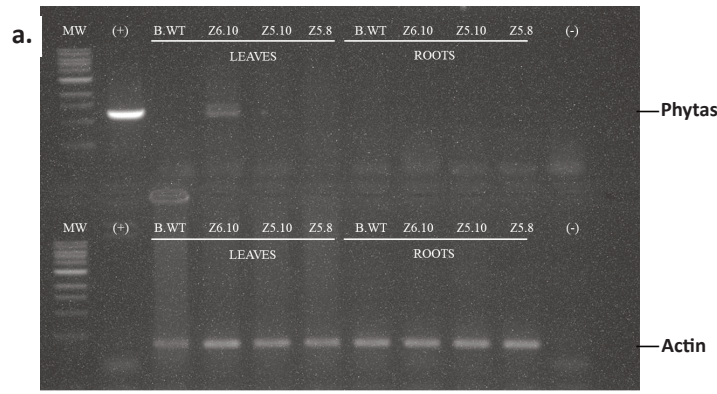

b.
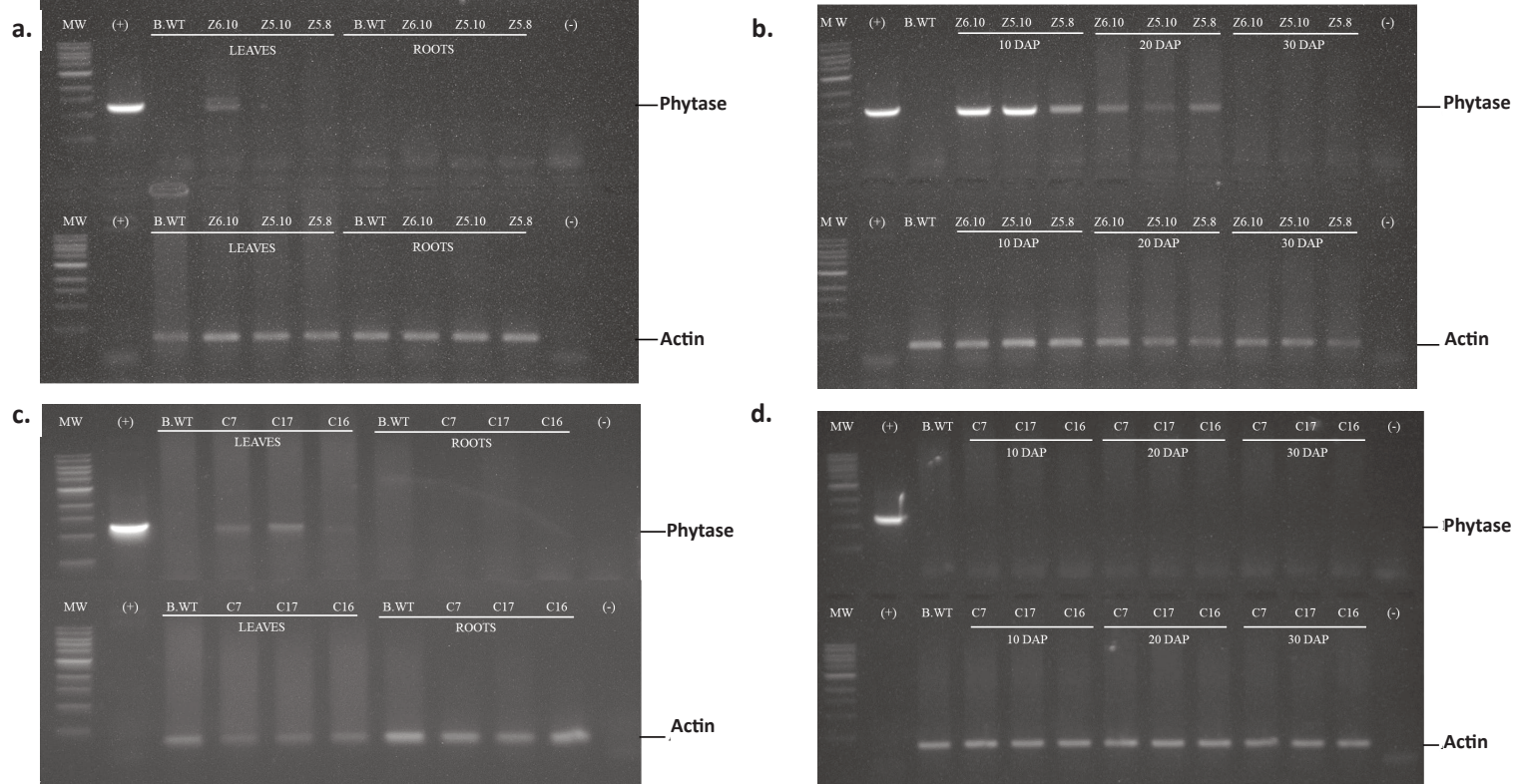

d.

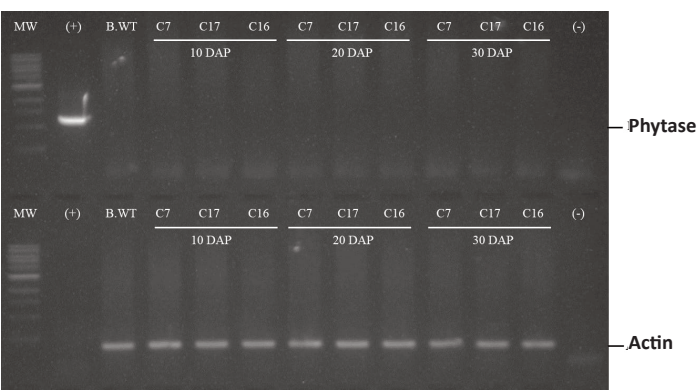

Figure 1. Phytase transgenic maize reverse-transcriptase PCR analysis at different organs ( $a$ and $c$ ) and different developmental stages ( $b$ and d). RNA was extracted from immature seeds (10 and 20 DAP), mature seeds (Mature), leaves or roots. Actin primer is utilized as internal control. MW molecular weight marker (1kb), (-) as template of negative control nuclease free water, (+) as template of plasmid control, B.WT as B104 non transgenic, DAP days after pollination.

which is 30 DAP, there was no ribbon amplification at $1200 \mathrm{bp}$ in size (Figure $1 \mathrm{~b}$ ). The expression of phytase genes in transgenic maize plants using $27-\mathrm{kDa}$ $\gamma$ Zein promoter showed that at number P6.10 phytase genes were not only expressed in seeds but phytase genes were also expressed in the leaves of maize plants. This was contrary to the $27-k D a ~ \gamma$ Zein's existence, which expressed unique genes in endosperm. This also occurs in transgenic maize plants whose expression amylopullulanase (APU) gene applied 27-kDa $y$ Zein promoter (Nahampun et al., 2013).

Mismatching gene expression with 27-kDa $y$ Zein promoter in APU transgenic maize was found in a number that expressed APU in all tissues observed, in leaves, roots and also in immature seedlings aged 10 and 20 days after pollination. The transgene inserted behind regulatory elements that bypass the tissuespecific promoter may be the cause (Nahampun et al., 2013). Transgenic phytase maize with 27-kDa $\gamma$ Zein promoter shows that phytase genes were only expressed in early seed development, at the age of 10 and 20 DAP, whereas in mature endosperm that is 30 DAP phytase transcript was very low and could not even be observed because seed development has led to translation by the formation of protein when the seeds are ripe. According to Woo et al., (2001) the zein transcript seeds were high at the beginning of development when the seeds were not yet ripe and when the seeds began to do the transcript maturation process that gradually decreased. Guo el al., (2013) showed that a 27-kDa $\gamma$ protein Zein was active in the initial stages of protein formation but not in the final stages of protein formation.

Phytase gene expression in transgenic maize plant with CaMV 35 S promoter was observed in three numbers and in several different parts, namely in leaves, roots, and fruit. The results of gene expression semiquantitative indicate that phytase genes were expressed in the leaves number $\mathrm{C} 7$ and $\mathrm{C} 17$ that were expressed higher than in number $\mathrm{C} 16$ number. This was indicated by the band thickness at $\mathrm{C} 7$ and $\mathrm{C} 17$ which was higher than in number $\mathrm{C} 16$. Phytase gene expression was shown by the amplification that produced a band at $1200 \mathrm{bp}$ size which is in accordance with the positive control of the plasmid used. At the root of transgenic phytase plants with CaMV 35 S promoter, the results showed that phytase genes were not expressed at the roots of transgenic plants. This could be seen from the absence of bands produced on the PCR with phytase primers, but PCR on actin primers produced bands at $352 \mathrm{pb}$ in size (Figure 1c).

Phytase gene expression on the development of transgenic maize with CaMV 355 promoter observed 
at three different numbers shows that in all transgenic numbers of maize no expression of phytase genes can be observed. This can be seen from the absence of band amplification from PCR results using phytase primers which will produce bands at $1200 \mathrm{bp}$ in all samples and various stages of development of maize aged 10, 20, and 30 DAP but PCR results in primary actin at the same sample used in testing using phytase primers produced a band at $352 \mathrm{bp}$. These results indicate that phytase genes were indeed not expressed in phytase transgenic maize with a CaMV 35 S promoter (Figure 1d).

Expression of phytase genes in transgenic plants with CaMV 355 promoters showed expressions that were not in accordance with constitutive promoter traits in which genes can be expressed in all parts of plants and various growth phases. In this research, phytase expression could only be seen in the leaves, while the roots and seeds were not found phytase expression. In transgenic rice plants with the CaMV 35 s promoter, GUS was not expressed in all cell types, and was not as well detected in the palea, stigma, or stamens, indicating inappropriate expression of this gene (Terada and Shimamoto, 1990). The CaMV $35 S$ promoter phytase gene was not expressed in all parts of the plant. This is due to the gene build not being fully incorporated into the plant genome or the fact that there are several copies of genes found in the genome (multiple copies). Multiple copies of the inserted gene can cause gene silencing (silencing) and changes in gene expression (Pawlowski and Somers, 1996). Due to the presence of the P35S region in both the CaMV genome and many GMO constructs, CaMV infection of non-GM plants can result in false-positive results in several GMO detection techniques (Bak and Emerson, 2020).

The phytase enzyme activity test on transgenic maize with 27-kDa $\gamma$ Zein promoter and the enzyme activity in transgenic plants was higher than the activity of phytase enzymes in non-transgenic plants, according to the CaMV 355 promoter. Similar observations were also observed in transgenic soybeans that expressed phytase genes. Transgenic soybeans produced enzyme activity 10 times higher than non-transgenic plants (Chiera et al., 2004). The enzyme activity in maize with CaMV 35 S promoter on average had almost the same activity as nontransgenic maize. This also correlated with the results of the semiquantitative gene expression test which showed that no transcripts were found in transgenic maize with CaMV 355 promoter at various growth phases. CaMV $35 \mathrm{~S}$ was ineffective in promoting transgenic expression during cotton boll formation, in Brassica juncea germ line tissues, and in darkgrown tissues of the moss Physcomitrella patens (Koramutla et al., 2016).

\section{Phytase enzyme activity in maize seed}

Phytase enzyme activity was analyzed by the phosphomolybdate colorimetric analysis method (Bae et al., 1999). The seeds used in the phytase enzyme activity experiment were $\mathrm{T} 2$ seeds obtained from phytase transgenic maize $\mathrm{T} 1$ crossed with no transgenic maize B104. The analysis was carried out on mature seeds, before protein isolation was done prior to the checking that the seeds used in the phytase enzyme activity assay contained phytase genes by conducting PCR on seeds with phytase specific primers. Three transgenic lines were selected

Table 1. Phytase enzyme activity in maize transgenic event T2 seeds

\begin{tabular}{lccc}
\hline \multirow{2}{*}{ Event ID } & \multicolumn{3}{c}{ Phytase enzyme activity (unit per $\mu \mathrm{g}$ ) } \\
\cline { 2 - 4 } & Kernel 1 & Kernel 2 & Kernel 3 \\
\hline Z6.10 & 0.35 & 0.35 & 0.26 \\
Z5.10 & 0.32 & 0.29 & 0.29 \\
Z5.8 & 0.29 & 0.34 & 0.29 \\
C7 & 0.21 & 0.25 & 0.21 \\
C17 & 0.21 & 0.19 & 0.22 \\
C16 & 0.17 & 0.17 & 0.16 \\
B104-WT & 0.20 & 0.22 & \\
\hline
\end{tabular}

Remarks: Each event having three kernels that were analyzed. The activity of phytase was randomly measured in one kernel. 
from each promoter. Table 1 shows that the phytase enzyme activity in the 27-kDa $\gamma$ Zein promoter was higher in transgenic plants than in non-transgenic plants. Phytase enzyme activity with the $27-k D a ~ y$ Zein promoter at number Z6.10 was the highest level of expression, with phytase activity ranging from $0.24-0.35$ units per $\mu$ g protein. Number Z5.10 had almost the same phytase expression level 0.290.32 units per $\mu$ g protein. The phytase activity at number Z5.8 was also almost the same as 0.29-0.34 units per $\mu \mathrm{g}$ protein. Phytase enzyme activity in transgenic seed with CaMV 35 S at number C7 showed the highest level of expression with phytase activity ranging from $0.21-0.25$ units per $\mu$ g protein. Number $\mathrm{C} 17$ had phytase enzyme activity from 0.19-0.22 units per $\mu \mathrm{g}$ protein and number $\mathrm{C} 16 \mathrm{had}$ phytase enzyme activity $0.16-0.17$ units per $\mu \mathrm{g}$ protein. In phytase with CaMV 355 promoter the activity of phytase enzymes was lower compared to phytase enzyme activity with seed spesific promoters and almost the same as non-transgenic plants. Phytase enzyme activity in 27-kDa $\gamma$ Zein promoter was higher than phytase enzyme activity in CAMV 35S promoter. Chen et al. (2008) reported that the activity of phytase in transgenic maize seeds was about 2,200 units per kg of seed. When phytase expression in Arabidopsis roots increased dramatically, the signal peptide was attached to the $\mathrm{N}$ end of the $A$. niger phyA protein. The signal peptide in PSPH3303T-Phy may be the reason for the increased frequency of high expression occurrences (Richardson et al., 2001).

\section{CONCLUSIONS}

The phytase gene is highly expressed in the maize seed in transgenic plants with a 27-kDa $y$ Zein promoter, but number Z6.10 was also expressed in the leaves, while in CaMV 355 promoter the phytase gene was not expressed in the plant, but in the leaves. Phytase enzyme activity showed that transgenic maize driven by 27-kDa $>$ Zein and CaMV 35S promoter was higher than non-transgenic maize.

\section{ACKNOWLEDGMENTS}

The authors would like to thank to PT. BISI International Tbk for financial support, Hartinio N. Nahampun, Ph.D. from PT. BISI International, and Dr. Irawan Tan from PT. Charoen Pokphand Indonesia for the help of Phytase gene.

\section{REFERENCES}

Abid, N., Khatoon, A., Maqbool, A., Irfan, M., Bashir, A., Asif, I., Shahid, M., Saeed, A., BrinchPedersen, H., and Malik, K. A. (2017). Transgenic expression of phytase in wheat endosperm increases bioavailability of iron and zinc in grains. Transgenic Research, 26(1), pp. 109-122.

Bae, H.D., Yanke, L.J., Cheng, K.J., and Selinger, L.B. (1999). A novel staining method for detecting phytase activity. Journal of Microbiological Methods, 39(1), pp 17-22.

Bak, A. and Emerson, J.B. (2020). Cauliflower mosaic virus (CaMV) biology, management, and relevance to GM plant detection for sustainable organic agriculture. Frontiers in Sustainable Food Systems, 4(21), pp. 1-8.

Belgaroui, N., Zaidi, I., Farhat, A., Chouayekh, H., Bouain, N., Chay,S., Curie, C., Mari, S., Masmoudi, K., Davidian, J.C., Berthomieu, P., Rouached, H., and Hanin, M. (2014). Overexpression of the bacterial phytase US417 in Arabidopsis reduces the concentration of phytic acid and reveals its involvement in the regulation of sulfate and phosphate homeostasis and signaling. Plant and Cell Physiology, 55(11), pp. 1912-1924.

Belgaroui, N., Lacombe, B., Rouached, H., and Hanin, M. (2018). Phytase overexpression in Arabidopsis improves plant growth under osmotic stress and in combination with phosphate deficiency article. Scientific Reports, 8(1), pp. 1-12.

Borlini, G., Rovera, C., Landoni, M., Cassani, E., and Pilu, R. (2019). Ipa1-5525: A New Ipa1 mutant isolated in a mutagenized population by a novel non-disrupting screening method. Plants (Basel), 8(7), pp. 209.

Bradford, M.M. (1976). A rapid and sensitive method for the quantitation of microgram quantities of protein utilizing the principle of protein-dye binding. Anal. Biochem., 72, pp. 248-254.

Chen, R., Guangxing, X., Ping, C., Bin,Y., Wenzhu, Y., Qianli, M., Yunliu, F., Zuoyu, Z., Mitchell, C. T., and Jinrui, S.(2008). Transgenic maize plants expressing a fungal phytase gene. Transgenic Research, 17(4), pp. 633-643.

Chiera, J.M., Finer, J.J., and Grabau, E.A. (2004). Ectopic expression of a soybean phytase in developing seeds of Glycine max to improve phosphorus availability. Plant Molecular Biology, 56(6), pp. 895-904. 
Corrêa, T.L.R., and de Araújo, E.F. (2020). Fungal phytases: from genes to applications. Brazilian Journal of Microbiology, 51, pp. 1009-1020.

Coulibaly, A., Brou, K., and Jie, C. (2011). Phytic acid in cereal grains: structure, healthy or harmful ways to reduce phytic acid in cereal grains and their effects on nutritional quality. American Journal of Plant Nutrition and Fertilization Technology, 1, pp. 1-22.

Dersjant, L.Y., Awati, A., Schulze, H., and Partridge, G. (2015). Phytase in non-ruminant animal nutrition: a critical review on phytase activities in the gastrointestinal tract and influencing factors. J. Sci. Food Agric., 95(5), pp. 878-896.

Erpel, F., Restovic, F., and Arce-Johnson, P. (2016). Development of phytase expressing Chlamydomonas reinhardtii for monogastric animal nutrition. BMC Biotechnol., 16(29), pp. 1-7.

Frame, B.R., Marcy, M., Rosemarie, S., and Wang, K. (2011). Genetic transformation using maize immature zygotic embryos. Plant embryo culture: methods and protocols. Methods Molecular Biology, 710, pp. 327-341.

Geetha, S., Beslin, J., Joshi,K., Kumar, K., Arul, L., Kokiladevi, E., Balasubramanian P., and Sudhakar D. (2019). Genetic transformation of tropical maize (Zea mays L.) inbred line with a phytase gene from Aspergillus niger. 3 Biotech, 9(6), pp. 1-10.

Gontia, I., Tantwai, K., Rajput, L. P. S., and Tiwari, S. (2012). Transgenic plants expressing phytase gene of microbial origin and their prospective applications as feed. Food Technol. Biotechnol., 50(1), pp. 3-10

Guo, X., Yuan, L., Chen, H., Sato, S.J., Clemente, T.E., and Holding, D.R. (2013). Nonredundant function of zeins and their correct stoichiometric ratio drive protein body formation in maize endosperm. Plant Physiol., 162(3), pp. 1359-1369.

Joshi, J.B., Geetha S., Singh, B., Kumar, K.K., Kokiladevi, E., Arul, L., Balasubramanian, P., and Sudhakar, D. (2015). A maize $\alpha$-zein promoter drives an endosperm-specifc expression of transgene in rice. Physiol. Mol. Biol. Plants, 21(1), pp. 35-42

Koramutla, M.K., Bhatt, D., Negi, M., Venkatachalam, P., Jain, P.K., and Bhattacharya, R. (2016). Strength, stability, and cis-motifs of in silico identified phloem-specific promoters in Brassica juncea (L.). Frontiers in Plant Science, 7, pp. 1-12.
Lei, X.G., Weaver, J.D., Mullaney, E.U.A., and Azain, M.J. (2013). Phytase a new life for an old enzyme. Annual Rev. Anim. Biosci., 1, pp. 283-309.

Moeller, L., Gan, Q., and Wang, K. (2009). A bacterial signal peptide is functional in plants and directs proteins to the secretory pathway. $J$. Exp. Bot., 60(12), pp. 3337-3352.

Nahampun, H.N., Lee, C.J., Jane, J.L., and Wang, K. (2013). Ectopic expression of bacterial amylopullulanase enhances bioethanol production from maize grain. Plant Cell Rep., 32(9), pp. 1393-405.

Pawlowski, P. and Somers, A. (1996). Transgene Inheritance in plant genetically engineered by microprojectile bombardment. Mol. Biotechnol., 6(1), pp. 17-30.

Reddy, C.S., Vani, K., Pandey, S., Vijaylakshmi, M., Reddy, P.C.O., and Kaul, T. (2013). Manipulating microbial phytases for heterologous expression in crops for sustainable nutrition. Ann. Plant Sci., 2, pp. 436-454.

Richardson, A.E., Hadobas, P.A., and Hayes, J. (2001). Extracellular secretion of Aspergillus phytase from Arabidopsis roots enables plants to obtain phosphorus from phytate. Plant J., 25(6), pp. 641-649

Selle, P.H., and Ravindran. (2007). Phytate-degrading enzymes in pig nutrition. Livestock Science, 113(2-3), pp. 99-122.

Singh, B. and Satyanarayana, T. (2011). Microbial phytases in phosphorous acquisition and plant growth promotion. Physiol. Mol. Biol. Plants, 17(2), pp. 93-103.

Singh, N., Sonia, K., Kanu, P., Rajneesh, J., and Rakesh Y. (2018). Phytase: The feed enzyme, an overview. In: Gahlawat, S., Duhan, J., Salar, R., Siwach, P., Kumar, S., Kaur, P. (eds)., Advances in Animal Biotechnology and its Applications, $1^{\text {st }}$ ed. Singapore: Springer, pp. 269-327.

Sunilkumar, G., LeAnne, M., Emily, L.F., Chandrakanth, E., and Keerti, S. R. (2002). Developmental and tissue-specific expression of CaMV 35S promoter in cotton as revealed by GFP. Plant Molecular Biology, 50(3), pp. 463-479.

Terada, R. and Shimamoto, K. (1990). Expression of CaMV 35S-GUS gene in transgenic rice plants. MGG Molecular \& General Genetics, 220(3), pp. 389-392.

Wang, Y., Ye, X., Ding. G., and Xu, F. (2013). Over expression of phyA and appA genes improves soil organic phosphorus utilization and seed phytase activity in Brassica napus. PLoS One, 8(4), e60801. 
Woo, Y.M., Hu, D.W., Larkins, B.A. and Jung. R. (2001). Genomics analysis of genes expressed in maize endosperm identifies novel seed proteins and clarifies patterns of zein gene expression. Plant Cell, 13(10), pp. 2297-2317.

Woyengo, T.A., and Nyachoti, C.M. (2013). Review: Anti-nutritional effects of phytic acid in diets for pigs and poultry current knowledge and directions for future research. Can. J. Anim. Sci., 93, pp. 9-21.
Yu, S., Cowieson, A., Gilbert, C., Plumstead, P., and Dalsgaard, S. (2012). Interactions of phytate andmyoinositol phosphate esters (IP1-5) including IP5 isomers with dietary protein and iron and inhibition of pepsin. J. Anim. Sci., 90(6), pp. 1824-1832. 